\title{
Essential oils in aerial parts of Myrcia tomentosa: composition and variability
}

\author{
Fabyola A. S. Sá, ${ }^{* 1}$ Leonardo L. Borges, ${ }^{1}$ Joelma A. M. Paula, ${ }^{2}$ \\ Bruno L. Sampaio, ${ }^{1}$ Pedro H. Ferri, ${ }^{3}$ José R. Paula ${ }^{1}$
}

\author{
${ }^{1}$ Laboratório de Pesquisa em Produtos Naturais, Faculdade de Farmácia, \\ Universidade Federal de Goiás, Brazil; \\ ${ }^{2}$ Unidade Universitária de Ciências Exatas e Tecnológicas, Universidade Estadual \\ de Goiás, Brazil; \\ ${ }^{3}$ Laboratório de Bioatividade Molecular, Instituto de Química, Universidade \\ Federal de Goiás, Brazil.
}

\begin{abstract}
Species in the Myrtaceae family are used in folk medicine to treat gastrointestinal disorders, infectious diseases and hemorrhagic conditions and are known for their essential oil contents. Gas chromatography coupled with mass spectrometry (GC-MS) was used to characterize the chemical composition of essential oils of the leaves, stem bark and flowers of Myrcia tomentosa (Aubl.) DC., as well as to assess the chemical variability in the constituents of the essential oils of the leaf. Soil and foliar analyses were also performed to determine the mineral compositions. Principal component analysis (PCA) was used to examine the interrelationships between the obtained data. The most abundant component in the essential oils of the flowers was $(2 E, 6 E)$-methyl farnesoate, whereas hexadecanoic acid was the most abundant essential oil component in the stem bark. The leaf essential oils showed seasonal variation in their chemical composition, with bicyclogermacrene and $(2 E, 6 E)$-methyl farnesoate as the major chemical components. Forty-four constituents were identified, and only nine compounds were found in all of the samples. Sesquiterpenes were mainly produced in the flowers and leaves. The PCA showed a positive correlation between the oxygenated sesquiterpenes and the foliar nutrients $\mathrm{Cu}$ and $\mathrm{P}$. Significant statistical correlations were verified between the climatic data, foliar nutrients and essential oil compositions.
\end{abstract}

Revista Brasileira de Farmacognosia Brazilian Journal of Pharmacognosy 22(6): 1233-1240, Nov./Dec. 2012

Article

Received 7 Jul 2012

Accepted 14 Sep 2012

Available online 11 Oct 2012

Keywords:

bicyclogermacrene

goiaba-brava

myrtaceae

PCA

seasonality

ISSN 0102-695X

http://dx.doi.org/10.1590/S0102$695 \mathrm{X} 2012005000120$

\section{Introduction}

The Brazilian Savanna is recognized as the richest source of biodiversity the world, with more than 6500 plant species already cataloged, over 220 of which have medicinal uses (MMA, 2009). In Brazil, the Myrtaceae family is one of the most important floras, containing 23 genera and approximately 130 species, and several species are used in folk medicine for the treatment of gastrointestinal disorders, infectious diseases and hemorrhagic conditions. Among the species of the Myrtaceae family, Psidium guajava L. and species of Eugenia, such as Eugenia punicifolia (Kunth.) DC, Eugenia jambos L., Eugenia uniflora L. and Eugenia dysenterica DC (Rodrigues \& Carvalho, 2001; Souza et al., 2002; Di Stasi et al., 2002; Pessini et al., 2003; Fiuza et al., 2008) are exemplary. This family includes several species that are characterized by the presence of essential oils (Rodrigues \& Carvalho, 2001; Holetz et al., 2002; Gondim et al., 2006; Amaral et al., 2006).
Although biological activities have often been described for aromatic herbs, many Myrtaceae species do not show a relationship between the presence of certain essential oils and such biological activities; rather, numerous biological activities that have been attributed to these plants are the result of constituents acting synergistically (Cunha, 2005).

One activity frequently described for these essential oils is their antimicrobial activity, particularly antibacterial and antifungal properties. Examples of these species include the following: Syzygium aromaticum (L.) Merrirl et L. M. Perry, Thymus sp., Lavandula sp., Origanum vulgare L., Rosmarinus officinalis L. and Eucalyptus globulus Labill (Simões \& Spitzer, 2004; Cunha, 2005).

Studies examining the composition and biological properties of the essential oils found in several species of the Myrtaceae family (Limberger et al., 2001; Franco et al., 2005; Zabka et al., 2009; Magina et al., 2009) have been reported, and their 
antimicrobial properties have been emphasized. The work of Cerqueira et al. (2007) on seasonal variation and antimicrobial activity and Alarcón et al. (2009) on chemical composition and antibacterial activity are examples of such antimicrobial studies for the genus Myrcia. Souza (2009) analyzed the chemical composition of nine species of the Myrtaceae family, two of which belonged to the genus Myrcia, Limberger et al. (2004) analyzed the composition of nine species of the genus Myrcia, and Zoghbi et al. (2003) analyzed three species.

The genus Myrcia has 300 species (Judd et al., 2009), for which a range of pharmacological activities have been described (Hecht, 1984; Almeida, 1993; Cerqueira et al., 2007; Xu et al., 2011). Within this genus, Myrcia tomentosa, popularly known as "goiababrava", can be found from Panama, northern Venezuela and Guyana to southeast Brazil (McVaugh, 1969) and is often cited in works on the flora, phytosociology and characterization of the Savanna/Cerrado (Mahmoud et al., 2003; Teixeira et al., 2004; Morais \& Lombardi, 2006). However, few works report pharmacognostic or phytochemical studies for this species (Dianese et al., 1993; Cardoso \& Sajo, 2006; Rossatto et al., 2009, Cardoso et al., 2009), and no reports have been found concerning its popular use.

Considering the wide distribution of volatile oils in higher plants and that the Myrtaceae family is considered rich in volatile oils, this study aimed to study the chemical composition of essential oils extracted from the aerial parts (leaves, flowers and stem bark) of $M$. tomentosa and to evaluate the seasonal variation in leaf constituents over the course of a year.

\section{Materials and Methods}

\section{Plant material}

Samples of Myrcia tomentosa (Aubl.) DC., Myrtaceae, were collected in Hidrolândia-GO, Brazil (16 53'59.4”S 49¹3'29.4”W) and identified by Prof. José Realino de Paula. A voucher specimen was deposited in the Herbarium of the Federal University of Goiás (code number 41318). Six leaf samples were collected every two months, from June 2009 to April 2010. One sample of stem bark (October 2008) and one sample of the flowers (October 2009) were also collected. The leaves were air-dried at room temperature, and the stem bark was dried in a forced air oven at $40^{\circ} \mathrm{C}$; both tissue types were pulverized in a knife mill and then used for extraction of the essential oils. Fresh material was used for the extraction of essential oils from the flowers.

\section{Essential oil extraction}

The essential oils of the aerial parts of $M$. tomentosa were obtained by hydrodistillation in a modified Clevenger-type apparatus $(2 \mathrm{~h})$. After extraction, each essential oil sample was dried over anhydrous sodium sulfate and stored at $-20{ }^{\circ} \mathrm{C}$ for further analysis.

\section{GC-MS analysis of essential oils}

The essential oils obtained were analyzed using a gas chromatograph interfaced with a mass selective detector (CG-MS), Shimadzu QP5050A, using an ionization voltage of $70 \mathrm{eV}$. A fused silica capillary column was utilized (CBP - 5; $30 \mathrm{~m} \mathrm{x} \mathrm{0,25}$ $\mathrm{mm} \times 0,25 \mu \mathrm{m})$ and helium was used as the carrier gas

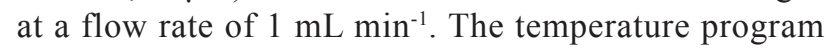
used was as follows: ramp up from 60 to $240{ }^{\circ} \mathrm{C}$ at $3{ }^{\circ} \mathrm{C}$ $\mathrm{min}^{-1}$, increase to $280{ }^{\circ} \mathrm{C}$ at $10{ }^{\circ} \mathrm{C} \mathrm{min}^{-1}$, and complete with $10 \mathrm{~min}$ at $280{ }^{\circ} \mathrm{C}$. The injection volume was 1 $\mu \mathrm{L}$ diluted with $\mathrm{CH}_{2} \mathrm{Cl}_{2}$ at a ratio 1:5. The essential oil constituents were identified by comparing their mass spectra with those from the National Institute of Standards and Technology (NIST, 1998), as well as by comparing the mass spectra and calculated linear retention indices (RI) with values in the literature (Adams, 2007). Retention indices were obtained by co-injection with a mixture of linear hydrocarbons, $\mathrm{C}_{9}$ $\mathrm{C}_{22}$ (Sigma, USA) and calculated using the equation of Van Den Dool \& Kratz (1963). The percentage of each component was calculated to normalize for the area in the chromatogram obtained using a Varian gas chromatograph (FID) equipped with a ZB-5 fused silica capillary column that was $30 \mathrm{~m} \times 0.25 \mathrm{~nm}$ with $0.25 \mu \mathrm{m}$ film thickness (5\% phenylmethylpolysiloxane). The following temperature program was used: increase from 60 to $240{ }^{\circ} \mathrm{C}$ at $3{ }^{\circ} \mathrm{C} \mathrm{min}{ }^{-1}$, followed by an increase to $280{ }^{\circ} \mathrm{C}$ at $10^{\circ} \mathrm{C} \mathrm{min}^{-1}$, and complete with $10 \mathrm{~min}$ at 280 ${ }^{\circ} \mathrm{C}$. The carrier gas was $\mathrm{N}_{2}$, at a flow rate of $1.0 \mathrm{~mL} /$ min; the injector port and detector temperatures were $220^{\circ} \mathrm{C}$ and $240{ }^{\circ} \mathrm{C}$, respectively. Samples were injected by splitting, and the split ratio was 1:20.

\section{Soil and foliar nutrient analyses}

The analyses of the chemical composition of the soil and leaf nutrients were performed by the Laboratory of Soil and Foliar Analysis, School of Agronomy, Federal University of Goiás, according to the methodology of Silva (2009).

Approximately $1 \mathrm{~kg}$ of soil from the site of collection was taken from a depth of $30 \mathrm{~cm}$ in four locations around the specimens of M. tomentosa. For the analysis of foliar nutrients, leaf samples $(15 \mathrm{~g})$ were 
used. Three replicate measurements were performed per plant sample.

\section{Statistical analyses}

Principal component analysis (PCA) was used to examine the interrelationships between the climatic data, foliar nutrients and essential oil composition. Cluster analysis (CA) was used to examine the similarity of the samples in their constituent distribution, and hierarchical clustering was performed according to Ward's variance minimizing method (Ward, 1963). Prior to the multivariate analysis (PCA and CA), the data were preprocessed by auto-scaling and mean centering. A Pearson correlation analysis was employed to determine the association between the climatic data, foliar nutrients and essential oil composition obtained from leaves of $M$. tomentosa. All analyses were performed using the software Statistica 7 and Past 2.12 .

\section{Results and Discussion}

The percentage yields $(\mathrm{v} / \mathrm{w})$ of the leaf essential oils were $0.54 \%$, which was greater than the yield found in other species, such as Eugenia brasiliensis Lamarck, E. beaurepaireana (Kiaerskou), E. umbeliflora (Berg.) and Myrcia fallax (Rich.) DC, which contained 0.07, 0.20, 0.33 and $0.25 \%$, respectively, in studies by Magina et al. (2009) and Alarcón et al. (2009). The yield of essential oils in the fresh flowers was $0.31 \%(\mathrm{v} / \mathrm{w})$, a value close to that obtained by Alarcón et al. (2009) for Myrcia fallax flowers. The yield of bark essential oils was $0.10 \%(\mathrm{v} / \mathrm{w})$.

Thirty-one compounds were identified in the essential oils obtained from the bark and thirteen compounds were identified in the essential oils obtained from the flowers, representing 76.27 and $72.17 \%$ of all isolated compounds, respectively (Tables 1 and 2). (2E,6E)-Methyl farnesoate (14.39\%) and hexadecanoic acid $(22.05 \%)$ were the main compounds found in the stem bark, while in the flowers, the main compounds were espathulenol (7.36\%), (2Z,6Z)farnesol $(10.65 \%)$ and $(2 E, 6 E)$-methyl farnesoate $(14.28 \%)$. Sesquiterpenes were predominant in the flowers, as has previously been found in Myrcia fallax; however, guaiol $(27.5 \%)$ and aristolone $(24.5 \%)$ were the primary compounds found in Myrica fallax, while monoterpenes, represented by $\alpha$-pinene were the main components (62-87.3\%) present in Myrcia myrtifolia DC (Cerqueira et al., 2007; Alarcón et al., 2009).

As shown in Table 3, 44 components were identified, representing 95.3 to $99.24 \%$ of the total essential oil content; however, only nine compounds were found in all six leaf samples ( $\beta$-elemene, $(E)$ caryophyllene, (E)- $\beta$-farnesene, bicyclogermacrene, germacrene B, spathulenol, globulol, $\alpha$-cadinol and $(2 E, 6 E)$-methyl farnesoate) and their concentrations varied.

Table 1. Percentages of chemical constituents of Myrcia tomentosa bark oils.

\begin{tabular}{|c|c|c|}
\hline RI & Constituent & Amount (\%) \\
\hline 1100 & $n$-nonanal & 2.36 \\
\hline 1177 & terpinen-4-ol & 0.55 \\
\hline 1201 & $n$-decanal & 2.15 \\
\hline 1376 & $\alpha$-copaene & 0.96 \\
\hline 1455 & geranyl acetone & 1.04 \\
\hline 1456 & $(E)$ - $\beta$-farnesene & 0.52 \\
\hline 1523 & $\delta$-cadinene & 1.95 \\
\hline 1545 & $\alpha$-calacorene & 0.63 \\
\hline 1566 & dodecanoic acid & 1.00 \\
\hline 1578 & spathulenol & 2.05 \\
\hline 1583 & caryophyllene oxide & 2.14 \\
\hline 1642 & epi- $\alpha$-Muurolol & 1.19 \\
\hline 1646 & $\alpha$-muurolol (=Torreyol) & 1.11 \\
\hline 1654 & $\alpha$-cadinol & 1.80 \\
\hline 1676 & cadalene & 1.16 \\
\hline 1784 & $(2 E, 6 E)$-methyl farnesoate & 14.39 \\
\hline 1800 & $n$-octadecane & 0.54 \\
\hline 1807 & 2-ethyhexyl-salicylate & 0.77 \\
\hline 1829 & isopropyl tetradecanoate & 1.96 \\
\hline 1875 & $n$-hexadecanol & 0.75 \\
\hline 1900 & $n$-nonadecane & 1.53 \\
\hline 1913 & $(5 E, 9 E)$-farnesyl acetone & 1.50 \\
\hline 1960 & hexadecanoic acid & 22.05 \\
\hline 1988 & 1-eicosene & 1.96 \\
\hline 2000 & $n$-eicosane & 1.03 \\
\hline 2077 & $n$-octadecanol & 0.58 \\
\hline 2100 & $n$-heneicosane & 2.83 \\
\hline 2133 & linoleic acid & 2.59 \\
\hline 2189 & 1-docosene & 0.49 \\
\hline 2200 & $n$-docosane & 0.72 \\
\hline \multirow[t]{6}{*}{2300} & $n$-tricosane & 0.93 \\
\hline & oxygenated monoterpenes & 0.55 \\
\hline & sesquiterpene hydrocarbons & 6.26 \\
\hline & oxygenated sesquiterpenes & 9.06 \\
\hline & others & 60.4 \\
\hline & total & 76.27 \\
\hline
\end{tabular}

(E)- $\beta$-farnesene was identified in all samples comprising $6.14 \%$ of the total essential oil content in August and $8.49 \%$ in October. Bicyclogermacrene was also found in all samples, ranging from $4.73 \%$ of the total 
essential oil content in October to $14.71 \%$ in June. The amount of $(2 E, 6 E)$-methyl farnesoate in the samples also varied over the year, making up less of the total essential oil content in April (5.33\%) and more in October (47.29\%).

Table 2. Percentages of chemical constituents of Myrcia tomentosa flower oils.

\begin{tabular}{clc}
\hline RI & \multicolumn{1}{c}{ Constituent } & Amount (\%) \\
\hline 1455 & geranyl acetone & 0.87 \\
1578 & spathulenol & 7.36 \\
1590 & globulol & 5.97 \\
1592 & viridiflorol & 0.31 \\
1654 & $\alpha$-cadinol & 3.61 \\
1684 & $(2 Z, 6 Z)$-farnesal & 6.86 \\
1698 & $(2 Z, 6 Z)$-farnesol & 10.65 \\
1713 & $(2 E, 6 Z)$-farnesal & 4.40 \\
1715 & $(2 E, 6 Z)$-farnesol & 2.17 \\
1741 & $(2 E, 6 E)$-farnesal & 5.36 \\
1784 & $(2 E, 6 E)$-methyl farnesoate & 14.28 \\
1865 & benzyl salicylate & 5.99 \\
2043 & kaurene & 3.47 \\
& sesquiterpene hydrocarbons & 0.87 \\
& oxygenated sesquiterpenes & 46.69 \\
& others & 24.61 \\
\hline & total & 72.17 \\
\hline
\end{tabular}

(2E,6E)-Methyl farnesoate was the major component in samples collected in August, October, December and February comprising between 33.10\% and $47.29 \%$ of the total essential oil content. In the April sample, epi- $\alpha$-bisabolol was the major component, comprising $42.39 \%$ of the sample, while in June the main components were germacrene D $(18.96 \%),(2 E, 6 E)$-methyl farnesoate $(17.99 \%)$ and bicyclogermacrene $(14.71 \%)$.

The component $\gamma$-muurolene was not found in August and December, however, it comprised of $4.18 \%$ and $18.46 \%$ of the total essential oil content in February and April, respectively. These results show the high variability of the composition of the essential oils, which may be due factors including the time of collection, collection site, growing conditions, plant age, climatic conditions, season, soil composition and storage period (Oliveira et al., 1998; Farias, 2004; Cunha, 2005).

Although $(2 E, 6 E)$-methyl farnesoate was found in all of the essential oil samples, there is a difference in the chemical composition of the oils obtained from the bark, flowers and leaves of $M$. tomentosa, which can be seen in the dendrogram shown in Figure 2. Simões \& Spitzer (2004) reported that the volatile oils obtained from different tissues of the same plant may differ in their chemical composition.

Results obtained from the Principal Component (PCA) and Cluster analyses showed a high level of chemical variability within the oils of $M$. tomentosa. Figure 1 shows the relative position of the samples according to the two first axes originated in the PCA. The majority of the data could be represented on two first axes, which explains $62.83 \%$ of the total variance (Component $1=36.16 \%$ and Component $2=26.67 \%$; Figure 1). The strong positive correlation between the oxygenated sesquiterpenes and the foliar nutrient variables $\mathrm{Cu}$ and $\mathrm{P}$ is clear; however, sesquiterpene hydrocarbons show the opposite behavior.

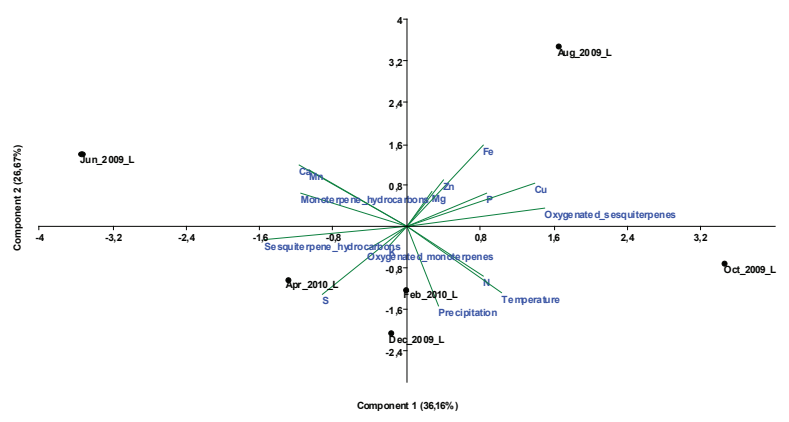

Figure 1. Scatterplot of samples of Myrcia tomentosa leaves collected in Hidrolândia-GO; Axes refer to scores from the samples; between parentheses refer to the explained variance on each Principal Component from PCA.

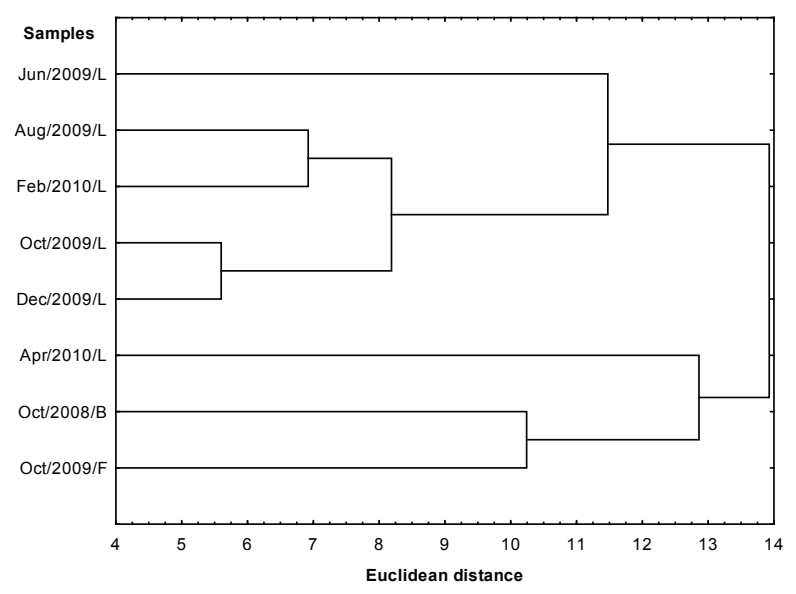

Figure 2. Dendrogram representing the chemical composition similarity relationships of Myrcia tomentosa oils (L: leaf; I: inflorescence; B: barks) according to Ward's variance minimization method (Ward, 1963).

Two samples (Oct/2008/B and Oct/2009/F) were added to the Cluster Analysis (Figure 2), and it was verified that the composition of oil obtained from the bark and flowers showed little similarity to the leaf essential oils. The dry months (Jun/2009/L and Aug/2009/L) were more similar than the months with higher rainfall. 
Table 3. Percentages of chemical constituents of Myrcia tomentosa leaf oils.

\begin{tabular}{|c|c|c|c|c|c|c|c|}
\hline \multirow{2}{*}{ RI } & \multirow{2}{*}{ Components } & \multicolumn{6}{|c|}{ Amount (\%) } \\
\hline & & Jun/2009 & Aug/2009 & Oct/2009 & Dec/2009 & $\mathrm{Feb} / 2010$ & Apr/2010 \\
\hline 990 & myrcene & 0.23 & - & - & - & - & - \\
\hline 1037 & $(Z)$ - $\beta$-ocimene & 0.35 & - & - & - & - & - \\
\hline 1096 & linalool & - & - & - & - & - & 0.16 \\
\hline 1338 & $\delta$-elemene & - & - & - & - & - & 0.25 \\
\hline 1376 & $\alpha$-copaene & 0.52 & - & 0.67 & 0.55 & 0.48 & 0.40 \\
\hline 1388 & $\beta$-bourbonene & 0.21 & - & - & 0.30 & 0.37 & - \\
\hline 1390 & $\beta$-elemene & 1.24 & 0.67 & 0.77 & 0.30 & 0.72 & 0.20 \\
\hline 1419 & $(E)$-caryophyllene & 5.23 & 3.57 & 6.46 & 5.74 & 4.57 & 3.43 \\
\hline 1432 & $\beta$-copaene & 0.34 & - & - & - & - & - \\
\hline 1434 & $\alpha$-trans-bergamotene & 0.46 & - & 0.47 & 0.33 & 0.31 & 0.31 \\
\hline 1441 & aromadendrene & 0.37 & - & - & - & - & \\
\hline 1442 & (Z)- $\beta$-farnesene & - & - & - & 0.30 & - & 0.68 \\
\hline 1454 & $\alpha$-humulene & 0.69 & - & 0.77 & 0.84 & 0.62 & 0.38 \\
\hline 1456 & $(E)$ - $\beta$-farnesene & 8.01 & 6.14 & 8.49 & 8.30 & 6.94 & 7.85 \\
\hline 1460 & allo-aromadendrene & 0.74 & - & 0.48 & 0.78 & - & - \\
\hline 1466 & 9-epi-(E)-caryophyllene & - & - & - & - & 0.61 & - \\
\hline 1466 & cis-muurola-4(14),5-dieno & - & - & - & - & - & 0.27 \\
\hline 1479 & $\gamma$-muurolene & 0.47 & - & 0.39 & - & 18.04 & 18.46 \\
\hline 1485 & germacrene D & 18.96 & 13.88 & 8.62 & 14.88 & - & - \\
\hline 1500 & bicyclogermacrene & 14.71 & 9.57 & 4.73 & 10.14 & 11.51 & 8.19 \\
\hline 1500 & $\alpha$-muurolene & - & - & 0.62 & 0.68 & 0.49 & 0.41 \\
\hline 1505 & $(E, E)-\alpha$-farnesene & 3.34 & - & - & - & - & - \\
\hline 1505 & $\beta$-bisabolene & - & - & - & - & - & 1.33 \\
\hline 1509 & germacrene $\mathrm{A}$ & - & - & 0.45 & 0.80 & - & 0.37 \\
\hline 1512 & $\delta$-amorphene & - & - & - & - & - & 3.47 \\
\hline 1513 & $\gamma$-cadinene & 0.44 & - & - & 0.28 & - & - \\
\hline 1523 & $\delta$-cadinene & 2.64 & 1.35 & 0.88 & 2.36 & 1.78 & - \\
\hline 1531 & $(E)-\gamma$-bisabolene & - & - & - & - & - & 0.39 \\
\hline 1561 & germacrene B & 1.12 & 0.87 & 0.77 & 0.71 & 0.78 & 0.39 \\
\hline 1563 & (E)-nerolidol & - & - & - & - & - & 0.46 \\
\hline 1568 & palustrol & 0.92 & - & - & - & - & - \\
\hline 1578 & spathulenol & 1.21 & 4.24 & 6.41 & 4.45 & 3.29 & 0.32 \\
\hline 1590 & globulol & 2.36 & 3.95 & 0.97 & 2.86 & 2.87 & 0.69 \\
\hline 1592 & viridiflorol & 1.80 & 2.54 & - & 1.55 & 1.33 & - \\
\hline 1600 & rosifoliol & 0.66 & - & - & - & 0.53 & - \\
\hline 1631 & muurola-4,10(14)-dien-1- $\beta$-ol & - & 0.96 & 0.28 & - & 0.37 & - \\
\hline 1642 & epi- $\alpha$-muurolol & 0.90 & 1.29 & 0.83 & - & 1.39 & 0.61 \\
\hline 1646 & $\alpha$-muurolol (=Torreyol) & 0.24 & - & - & - & 0.44 & 0.35 \\
\hline 1646 & cubenol & - & - & - & 0.89 & - & - \\
\hline 1654 & $\alpha$-cadinol & 1.13 & 1.84 & 1.15 & 1.33 & 2.08 & 0.78 \\
\hline 1684 & epi- $\alpha$-bisabolol & 10.01 & 5.49 & - & - & - & 42.39 \\
\hline 1713 & $(2 E, 6 Z)$-farnesal & 0.64 & 3.97 & 1.59 & 0.96 & 1.18 & - \\
\hline 1741 & $(2 E, 6 E)$-farnesal & 0.83 & 5.66 & 2.21 & 1.17 & 1.59 & - \\
\hline
\end{tabular}




\begin{tabular}{llcccccc}
\hline 1784 & $(2 E, 6 E)$-methyl farnesoate & 17.99 & 33.10 & 47.29 & 37.87 & 36.95 & 5.33 \\
& monoterpene hydrocarbons & 0.58 & - & - & - & - & - \\
& oxygenated monoterpenes & - & - & - & - & 0.16 \\
& sesquiterpene hydrocarbons & 59.49 & 36.05 & 34.57 & 47.29 & 47.22 & 46.78 \\
oxygenated sesquiterpenes & 38.69 & 63.04 & 60.73 & 51.08 & 52.02 & 50.93 \\
\hline total & 98.76 & 99.09 & 95.3 & 98.37 & 99.24 & 97.87 \\
\hline
\end{tabular}

In the Pearson correlation analysis, we found two strong significant correlations $(p<0.05)$ between the foliar $\mathrm{Cu}$ and sesquiterpene hydrocarbons $(\mathrm{R}=-0.87)$ and between foliar $\mathrm{Cu}$ and oxygenated sesquiterpenes $(\mathrm{R}=0.84)$. The observed strong negative correlation between foliar $\mathrm{Cu}$ and sesquiterpene hydrocarbons is consistent with inhibition of $\mathrm{Cu}$ by some sesquiterpene hydrocarbons, such as germacrene $\mathrm{D}$ and $\mathrm{B}$ and bicyclogermacrene, because the formation of sesquiterpenes from farnesyl diphosphate by germacrene $\mathrm{D}$ synthase in ginger is inactive in the presence of $\mathrm{Cu}^{2+}$ ions. This inhibitory effect was found in Zingiber officinale Roscoe, Zingiberaceae (Picaud et al., 2006). Thus, the data obtained from $M$. tomentosa showed that $\mathrm{Cu}$ seems to inhibit sesquiterpenes through this enzyme.

Sesquiterpenes were found predominantly in $M$. tomentosa leaves, as was found previously for Myrcia splendens (Sw.) DC (Souza, 2009), M. laruotteana Camb (Stefanello et al., 2007) and nine other Myrcia spp (Limberger et al., 2004). There appears to be variation in the major components, as was also observed for Myrcia macrocarpa DC (Souza, 2009).

The physicochemical properties of the soil are shown in Table 4 and indicate that it was dystrophic $(\mathrm{V}<50 \%)$ and moderately acidic $(\mathrm{pH} 5.4)$, with a low cation exchange capacity, and calcium and potassium were the principal cations in exchange with soil. For foliar nutrients in the leaves (Table 5), it was observed that the elements $\mathrm{N}, \mathrm{P}, \mathrm{K}, \mathrm{Mg}, \mathrm{S}$ and $\mathrm{Mn}$ showed little variation over the time course of the study. In October, the $\mathrm{Ca}$ level was lowest $(0.60 \mathrm{dag} / \mathrm{kg})$, while $\mathrm{Cu}$ was at its greatest level of all the samples $(31.0 \mathrm{mg} / \mathrm{kg})$. In August, the nutrients $\mathrm{Cu}(29.0 \mathrm{mg} / \mathrm{kg}), \mathrm{Zn}(100.0 \mathrm{mg} / \mathrm{kg})$ and $\mathrm{Fe}(527.0 \mathrm{mg} / \mathrm{kg})$ exhibited high levels in the leaves of $M$. tomentosa, and Fe decreased in December $(82.0 \mathrm{mg} / \mathrm{kg})$.

The PCA showed a positive correlation between oxygenated sesquiterpenes and the foliar nutrient variables $\mathrm{Cu}$ and $\mathrm{P}$, which was verified by significant statistical correlations between the climatic data, foliar nutrients and essential oil composition.

Table 4. Levels of mineral nutrients and fertility parameters of soil.

\begin{tabular}{lclc}
\hline \multicolumn{1}{c}{ Parameter } & Soil sample & \multicolumn{1}{c}{ Parameter } & Soil sample \\
\hline $\mathrm{Cu}\left(\mathrm{mg} / \mathrm{dm}^{3}\right)$ & 1.6 & $\mathrm{H}+\mathrm{Al}\left(\mathrm{cmol} / \mathrm{dm}^{3}\right)$ & 3.9 \\
$\mathrm{Fe}\left(\mathrm{mg} / \mathrm{dm}^{3}\right)$ & 79.1 & $\mathrm{CEC}\left(\mathrm{cmol} / \mathrm{dm}^{3}\right)$ & 6.0 \\
$\mathrm{Mn}\left(\mathrm{mg} / \mathrm{dm}^{3}\right)$ & 62.8 & $\mathrm{~m}(\%)$ & 0.0 \\
$\mathrm{Zn}\left(\mathrm{mg} / \mathrm{dm}^{3}\right)$ & 1.3 & $\mathrm{~V}(\%)$ & 34.7 \\
$\mathrm{O} . \mathrm{M} .(\%)$ & 1.3 & $\mathrm{Ca} / \mathrm{Mg}$ & 2.8 \\
$\mathrm{pH}\left(\mathrm{Ca} / \mathrm{Cl}^{2}\right)$ & 5.4 & $\mathrm{Mg} / \mathrm{K}$ & 2.8 \\
$\mathrm{P}\left(\mathrm{mg} / \mathrm{dm}^{3}\right)$ & 5.1 & $\mathrm{Ca} / \mathrm{K}$ & 7.9 \\
$\mathrm{~K}\left(\mathrm{mg} / \mathrm{dm}^{3}\right)$ & 69.0 & $\mathrm{Ca} / \mathrm{CEC}(\%)$ & 23.4 \\
$\mathrm{Ca}\left(\mathrm{cmol} / \mathrm{dm}^{3}\right)$ & 1.4 & $\mathrm{Mg} / \mathrm{CEC}(\%)$ & 8.4 \\
$\mathrm{Mg}\left(\mathrm{cmol} / \mathrm{dm}^{3}\right)$ & 0.5 & $\mathrm{~K} / \mathrm{CEC}(\%)$ & 3.0 \\
$\mathrm{Al}\left(\mathrm{cmol} / \mathrm{dm}^{3}\right)$ & 0.0 &
\end{tabular}

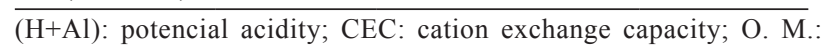
organic matter; V: base saturation; m: aluminum saturation.

Table 5. Levels of foliar macronutrients in the leaves of Myrcia tomentosa over the period from June 2009 to April 2010.

\begin{tabular}{ccccccc}
\hline Nutrients & Jun/09 & Aug/09 & Oct/09 & Dec/09 & Feb/10 & Apr $/ 10$ \\
\hline $\mathrm{N}(\mathrm{dag} / \mathrm{kg})$ & 1.26 & 1.34 & 2.02 & 1.40 & 2.12 & 1.60 \\
$\mathrm{P}(\mathrm{dag} / \mathrm{kg})$ & 0.154 & 0.176 & 0.243 & 0.14 & 0.05 & 0.08 \\
$\mathrm{~K}(\mathrm{dag} / \mathrm{kg})$ & 0.96 & 0.86 & 0.96 & 0.60 & 1.70 & 1.28 \\
$\mathrm{Ca}(\mathrm{dag} / \mathrm{kg})$ & 1.90 & 1.70 & 0.60 & 1.14 & 1.30 & 1.40 \\
$\mathrm{Mg}(\mathrm{dag} / \mathrm{kg})$ & 0.20 & 0.30 & 0.20 & 0.21 & 0.29 & 0.25 \\
$\mathrm{~S}(\mathrm{dag} / \mathrm{kg})$ & 0.06 & 0.01 & 0.01 & 0.12 & 0.09 & 0.12 \\
$\mathrm{Cu}(\mathrm{mg} / \mathrm{kg})$ & 4.0 & 29.0 & 31.0 & 7.0 & 5.0 & 6.0 \\
$\mathrm{Fe}(\mathrm{mg} / \mathrm{kg})$ & 184.0 & 527.0 & 300.0 & 82.0 & 121.0 & 162.0 \\
$\mathrm{Mn}(\mathrm{mg} / \mathrm{kg})$ & 441.0 & 420.0 & 110.0 & 191.0 & 310.0 & 420.0 \\
$\mathrm{Zn}(\mathrm{mg} / \mathrm{kg})$ & 13.50 & 100.0 & 10.4 & 18.0 & 67.0 & 19.0 \\
\hline
\end{tabular}


The results obtained in this work show that oil samples from $M$. tomentosa can vary in composition, depending on sampling period and the part of the plant from which they are extracted. M. tomentosa is a species that shows great potential to produce essential oils, and creating new perspectives for research into biological activities related to its essential oils.

\section{Acknowledgments} support.

The authors are grateful to CAPES for financial

\section{References}

Adams RP 2007. Identification of essential oil components by gas chromatography/mass spectrometry. $4^{\circ}$ ed. Illinois USA: Allured Publishing Corporation, Carol Stream, 804 p.

Alarcón LD, Peña AE, Gonzales N, Quintero A, Meza M, Usubillaga A, Velasco J 2009. Composition and antibacterial activity of the essential oil of Myrcia fallax (Rich.) DC. from Venezuela. Rev Soc Quim Peru 75: 221-227.

Almeida ER 1993. Plantas medicinais brasileiras: conhecimentos populares e cientificos. São Paulo: Hemus.

Amaral FMM, Ribeiro MNS, Barbosa-Filho JM, Reis AS, Nascimento FRF, Macedo RO 2006. Plants and chemical constituents with giardicidal activity. Rev Bras Farmacogn 16: 696-720.

MMA 2009. O Bioma Cerrado. Ministério do Meio Ambiente. http://www.mma.gov.br/, access in Marh 2009.

Cardoso CMV, Sajo MG 2006. Nervação foliar em espécies brasileiras de Myrtaceae Adans. Acta Bot Bras 20: 657-669.

Cardoso CMV, Proença SL, Sajo MG 2009. Foliar anatomy of the subfamily Myrtoideae (Myrtaceae). Aust J Bot 57: 148-161.

Cerqueira MD, Souza-Neta LC, Passos MGVM, Lima EO, Roque NF, Martins D, Guedes MLS, Cruz FG 2007. Seasonal variation and antimicrobial activity of Myrcia myrtifolia essential oils. J Braz Chem Soc 18: 998-1003.

Cunha AP 2005. Farmacognosia e Fitoquímica. Lisboa: Fundação Calouste Gulbenkian.

Di Stasi LC, Oliveira GP, Carvalhaes MA, Queiroz-Junior M, Tien OS, Kakinami SH, Reis MS 2002. Medicinal plants popularly used in the Brazilian Tropical Atlantic Forest. Fitoterapia 73: 69-91.

Dianese JC, Medeiros RB, Santos LTP, Sutton BC 1993. Coniella costae sp. nov. on leaves of Myrcia tomentosa from Brazilian cerrado. Mycol Res 97: 1234-1236.

Farias MR 2004. Avaliação da qualidade de matérias-primas vegetais. In: Simões CMO, Schenkel EP, Gosmann G, Mello JCP, Mentz LA, Petrovick PR (org.)
Farmacognosia: da planta ao medicamento. 5. ed. rev. ampl. Florianópolis: Ed. da UFSC; Porto Alegre: Ed. da UFRGS, p. 263-288.

Fiuza TS, Rezende MH, Sabóia-Morais SMT, Bara MTF, Tresvenzol LMF, Paula JR 2008. Caracterização farmacognóstica das folhas de Eugenia uniflora 1. (Myrtaceae). REF 5: 21-31.

Franco J, Nakashima T, Franco L, Boller C 2005. Composição química e atividade antimicrobiana in vitro do óleo essencial de Eucalyptus cinerea F. Mull. ex Benth., Myrtaceae, extraído em diferentes intervalos de tempo. Rev Bras Farmacogn 15: 191-194.

Gondim ANS, Oliveira VR, Silva LR, Silva BA, CondeGarcia EA 2006. Complete atrioventricular block on isolated guinea pig heart induced by an aqueous fraction obtained from Psidium guajava L. leaf. Rev Bras Farmacogn 16: 312-316.

Hecht SM 2009. Biologically active extracts from Myrcia fallax (Myrtaceae) Peru and method of obtaining same. US Patents. US n.4451459. 29 May 1984, http://www.freepatentsonline.com/4451459.html, accessed Mar 2009.

Holetz FB, Pessini GL, Sanches NR, Cortez DAG, Nakamura CV, Dias Filho BP 2002. Screening of some plants used en the Brazilian folk medicine for the treatment of infectious diseases. Mem Inst Oswaldo Cruz 97: 1027-1031.

Judd WS, Campbel CS, Kellongg EA, Steens PF, Donogue MJ 2009. Sistemática Vegetal: um enfoque filogenético. 3. ed. Porto Alegre: Artmed.

Limberger RP, Sobral MEG, Zuanazzi JAS, Moreno PRH, Schapoval EES, Henriques AT 2001. Biological activities and essential oil composition of leaves of Blepharocalyx salicifolius. Pharmaceut Biol 39: 308311.

Limberger RP, Sobral M, Henriques AT, Menut C, Bessière JM 2004. Óleos voláteis de espécies de Myrcia nativas do Rio Grande do Sul. Quim Nova 27: 916-919.

Magina MDA, Dalmarco EM, Wisniewski Jr A, Simionatto EL, Dalmarco JB, Pizzolatti MG, Brighente IC 2009. Chemical composition and antibacterial activity of essential oils of Eugenia species. J Nat Med 63: 345350 .

Mahmoud AGE, Virillo CB, Ribeiro DB, Ikemoto E, Hornink GG, Ricarte JD, Alcantara SF, Watanabe TM 2003. Chave dicotômica para identificação de espécies arbóreo-arbustivas de Cerrado do município de Itirapina - São Paulo. http://www2.ib.unicamp.br/ profs/fsantos/relatorios/bt791r1a2003.pdf, accessed Oct 2009.

McVaugh R 1969. Botany of the Guyana higland. Memoir New York Bot Gard 18: 55-286.

MMA 2009. O Bioma Cerrado. Ministério do Meio Ambiente. http://www.mma.gov.br/, accessed Mar 2009.

Morais PO, Lombardi JA 2006. A família Myrtaceae na reserva 
particular do Patrimônio Natural da Serra do Caraça, Catas Altas, Minas Gerais, Brasil. Lundiana 7: 3-32.

NIST (National Institute of Standards and Technology) 1998. PC version of the NIST/EPA/NIH Mass Espectral Database. Gaithersburg, MD: U.S. Department of Commerce.

Oliveira F, Akisue G, Akisue MK 1998. Farmacognosia, São Paulo: Atheneu.

Pessini GL, Holetz FB, Sanches NR, Cortez DAG, Dias Filho BP, Nakamura CV 2003. Avaliação da atividade antibacteriana e antifúngica de extratos de plantas utilizados na medicina popular. Rev Bras Farmacogn 13: 21-24.

Picaud S, Olsson ME, Brodelius M, Brodelius PE 2006. Cloning, expression, purification and characterization of recombinant $(+)$-germacrene D synthase from Zingiber officinale. Arch Biochem Biophys 452: 17-28.

Rodrigues VEG, Carvalho DA 2001. Levantamento etnobotânico de plantas medicinais no domínio do cerrado na região do alto Rio Grande - Minas Gerais. Cienc Agrotec 25: 102-123.

Rossatto DR, Hoffmann WA, Franco AC 2009. Características estomáticas de pares congenéricos de cerrado e mata de galeria crescendo numa região transicional no Brasil Central. Acta Bot Bras 23: 499-508.

Silva SC 2009. Manual de análises químicas de solos, plantas e fertilizantes. Brasília: Embrapa Informação Tecnológica.

Simões CMO, Spitzer V 2004. Óleos voláteis. In: Simões CMO, Schenkel EP, Gosmann G, Mello JCP, Mentz LA, Petrovick PR (org.) Farmacognosia: da planta ao medicamento. 5. ed. rev. ampl. Florianópolis: Ed. da UFSC; Porto Alegre: Ed. da UFRGS. p. 467-495.

Souza LKH, Oliveira CMA, Ferri PH, Santos SC, Júnior JGO, Miranda ATB, Lião LM, Silva MRR 2002. Antifungal properties of Brazilian Cerrado plants. Braz J Microbiol 33: 247-249.

Souza A 2009. Variabilidade dos óleos voláteis de espécies de Myrtaceae nativas da Mata Atlânticia. São Paulo, 351p. PhD Thesis, Instituto de Biociências, Universidade de São Paulo.

Stefanello MEA, Cervi AC, Wisniewski Jr A, Simionatto EL 2007. Essential oil composition of Myrcia laruotteana Camb. J Essent Oil Res 19: 466-467.

Teixeira MIJG, Araujo ARB, Valeri SV, Rodrigues RR 2004. Florística e fitossociologia de área de cerrado S.S. no município de Patrocínio Paulista, nordeste do Estado de São Paulo. Bragantia 63: 1-11.

Van Den Dool H, Kratz PDJA 1963. A generalization of the retention index system including linear temperature programmed gas-liquid partition chromatography. $J$ Chromatogr 11: 463-471.

Xu L, Gao J, Wang Y, Yu W, Zhao X, Yang X, Zhong Z, Qian $\mathrm{Z}$ 2011. Myrcia rubra extracts protect the liver from CC14-Induced Damage. eCAM 2011:1-9, doi 10.1093/ ecam/nep196.

Ward JH 1963. Hierarquical grouping to optimize an objective function. JASA 58: 236-244.

Zabka M, Pavela R, Slezakova L 2009. Antifungal effect of Pimenta dioica essential oil against dangerous pathogenic and toxinogenic fungi. Ind Crop Prod 30: 250-253.

Zoghbi MGB, Andrade EHA, Silva MHL, Carreira LMM, Maia JGS 2003. Essential oils from three Myrcia species. Flavour Frag J 18: 421-424.

\section{*Correspondence}

Fabyola Amaral da Silva Sá

Instituto de Patologia Tropical e Saúde Pública

Rua 235 s/n, Setor Universitário, 74605-050 Goiânia-GO, Brazil

jrealino@farmacia.ufg.br

Tel.: +556232096109

Fax.: +556232096363 